\title{
ランドサットデータによる浅海域のサンゴ礁抽出と水深推測
}

\section{An Extraction of the Coral Reef and Water Depth Using LANDSAT-5/TM}

\author{
全＼cjkstart炳 徳*, 後藤恵之輔*, 宇 野 史 郎** \\ Byungdug JUN, Keinosuke GOTOH, Shiroh UNO
}

\begin{abstract}
A new model to extract coral reef area was proposed and applied to an estimation model of bottom depth. Image density on 1540 pixels of LANDSAT/5-TM and provided data on depth and bottom condition from JODC (Japan Oceanographic Data Center) were used for mapping coral reef area and for estimating bottom depth.

Both models were adopted to Okinawa Main Island and Yaeyama Islands and discussed on its practical use. Moreover, limitations of applied model were also discussed and an errors analysis was performed. Depths from surface to $34 \mathrm{~m}$ were measured with RMS residuals of $3.38 \mathrm{~m}$ and 4.23 against the data obtained at fine atmospheric and the fine plus cloudy atmospheric conditions, respectively. Two and four bottom features models were compared each other on its application.

Finally, using two bottom features model described above, a three-dimensional image and a isodepth image were obtained by a personal computer at an area of Yaeyama Islands.
\end{abstract}

\section{1.はじめに}

近年, 海洋研究の分野でも, リモートセンシング技 術を導入し，海洋の情報を得るための広域性, 経済性, 同時性，反復性に優れたリモートセンシングの利点を 生している。リモートセンシングの利用により, 調査 資材，調査時期，調査に要する時間や費用などの既存 の調査方法の問題点を軽減するという点で, 多くの長 所を持っていると考えられる。

本研究では, 人工衛星データの特徵を生かし, 地球 観測衛星であるランドサットの TM データについて, (1)海底情報抽出モデルを作成した。また，(2)この海底 情報抽出モデルから得られたデー夕を用いて, 更に, サンゴ礁が卓越している地域を対象にした，水深推測 モデルを開発した。(3)ここで開発した海底情報抽出モ デルや水樑推測モデルは, 沖縄本島と八重山諸島に適 用し，その実用性について検討した。更に，(4)適用地

* 長崎大学工学部社会開発工学科

**海洋科学技術センター

「写真測量とリモートセンシング」Vol. 33, No. 4, 1994
域の水深推測結果をパソコンにより 3 次元表現と等水 深線表現を試みた。

\section{2. 本研究の手法}

本研究の手法としては以下の点に重点を起き, 研究 を進めた。

海底情報のサンゴ礁の抽出に当たっては, (1)浅海域 の潮位の差, (2)パスラジアンス項と太陽高度による影 響, (3)水深の影響など，3つの項目に対して補正を行 い，抽出精度を高めることに努めた。

水深推測モデルでは, (1)水深精度の高い結果をもた らす海底地質モデル1)の利用, (2)ただし, 海底地質は人 工衛星のデータから分離するが, (3)この海底地質はサ ンゴと非サンゴの 2 つの種類で分離する。

画像解析では, (1)水深結果の 3 次元表現, (2)各ピク セルごとの水深データから, 等水深線の抽出, (3)水深 ごとのカラースライス画像表現を試みた。

本研究で以上の点に重点をおいたのは, サンゴ礁抽 出においては, ランドサットデータによる多くの研 究2-5)で指摘された問題点 (1)潮位の差および水深の影 響が抽出精度を落とす。(2)砂も同質で判別)を補強し, 
精度の高いサンゴ礁情報を得るための目的があり，水 深推測手法に打いては，水深推測を行う海域の海底地 質が場所によって異なる場合，推測誤差が生じる問題 点6-9)を除き，海底地質モデルの問題点 ${ }^{1)}$ のつであ る，人の手による入力法のエラーと面倒な手作業を無 くすための目的があった。

以上の目的を満たすことにより，サンゴ礁が広がっ ている海域における，推測精度の高い水深推測モデル の手法を開発することができた。また，これらの水深 結果を 3 次元カラースライス画像として表現し, 視覚 に訴え易く現した。

\section{3. モデル理論と適用手法}

水深推測モデルは海底地質モデルの理論 ${ }^{1} に$ 基づい た。しかし，このモデルの問題点（海底地質情報を人 手により入力）を無くすために，モデルの海底地質情 報は，人工衛星デー夕から取得して用いた。

本研究で用いた水深推測モデルの一般式は次の通り である。

$$
\begin{aligned}
& \mathrm{Zc}=\mathrm{Bc} 0+\mathrm{Bc} 1 * \mathrm{Xc} 1+\ldots+\mathrm{Bcn} * \mathrm{Xcn} \cdots \cdots . . .(1) \\
& \mathrm{Zn}=\mathrm{Bo} 0+\mathrm{Bo} 1 * \mathrm{Xo} 1+\ldots+\mathrm{Bon} * \mathrm{Xon} \quad \cdots \cdots(2)
\end{aligned}
$$$$
\text { ここで, } Z \mathrm{c} \text { はサンゴ礁の水深, } \mathrm{Zn} \text { はサンゴ礁以外の }
$$
水深を示す。また, B ( c, o ) n は回帰分析により決まる 值であり，X(c,o)n はデー夕補正済みのデジタル值か ら求めた Ln (CCT 值一デー夕補正值：以下 Ln 值) 值 である。

\section{4.使用したデータ}

モデルと解析に用いたデータは，ランドサットー 5 号 TM の 4 回のデー夕（Table 1 参考）と海上保安庁 が1986年度に行った調査結果の水深原図である。また， モデル地域としては，サンゴ礁地域を含む浅い水深が 広がっている，沖縄本島の金武湾を選んだ。

Table 1 Specification of Satellite date Complojed on the present study

\begin{tabular}{lcccc}
\hline Data No. & No.1 & No.2 & No.3 & No.4 \\
\hline Platfrom & Landsat-5 & Landsat-5 & Landsat-5 & Landsat-5 \\
Sensor & TM & TM & TM & TM \\
Path/Row & $113-042$ & $113-042$ & $113-042$ & $113-042$ \\
Date & $1986 / 07 / 15$ & $1988 / 12 / 27$ & $1989 / 03 / 01$ & $1989 / 09 / 25$ \\
Time(G.M.T.) & $01-18-20$ & $01-26-00$ & $01-25-20$ & $01-21-20$ \\
Sun Elevation & 58 & 32 & 42 & 50 \\
Sensor Position & E128-06 & E128-10 & E128-08 & E128-09 \\
\hline
\end{tabular}

4 回のデー夕を用いたのは，季節的な影響を調へ， その影響のないモデルを開発するというねらいがあっ た。

\section{5.データの補正}

人工衛星デー夕により水深及び海底情報を解析する ためには，前処理としてのデー夕補正が必要である。 Fig. 1 の 1 は画像の幾何補正を示しており，2 は大気 補正，3 は撮影時間ごとに異なる潮位の差により生じ る海面高さの補正，それから 4 は海底地質ごとに当て はめられるモデル選択処理を意味している。

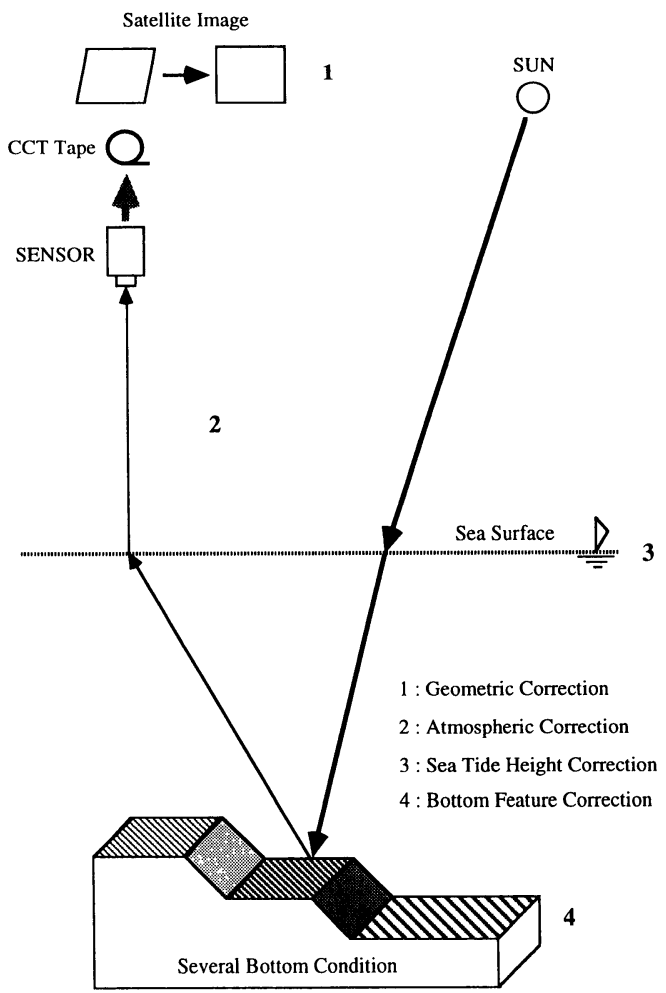

Fig. 1 Situation of data correction in this study

\section{1 幾何補正}

幾何補正の方法には, (1)理論的な補正式によるもの, （2）基準点を用いて決定する補正式によるもの，(3)前述 の(1)と(2)を組み合わせたものの 3 つに分けられる ${ }^{10) 。}$ 本研究で用いたのは，(2)に相当する非系統的補正と呼 ばれる地上基準点を用いた補正である。

地上基準点の 10 ポイントを用いて求めた，アフィン 
変換式の係数はカラムとラインがそれぞれ次の式のよ うに表される。

column $=3463.25 *$ latitude $+(-628.63)$

$*$ longitude +426056.65

line $=(-558.48) *$ latitude $+(-3822.85)$

$*$ longitude +172568.33

各々の式が持っている R.M.S.エラーは，カラムと ラインが各々1.69カラムと0.09ラインであった。

\section{2 大気補正}

本研究では，パスラジアンスと太陽高度の影響を大 気に関わる要因として補正した。

パスラジアンスについては，Hovis ${ }^{11} の$ 研究が補正 の必要性を良く説明している。パスラジアンスは海上 に位置する人工衛星のセンサーが受ける大気の影響を 示すもので, Hovisは，同じ海上の照度を $0.91 \mathrm{~km}$ と $14.90 \mathrm{~km}$ の高さで測定した結果より波長によって異 なる，大気影響の独特のパターンを説明している。こ のようなパスラジアンスの影響は，ランドサットのセ ンサーの場合, バンド 1 のが一番大きく, 次いでバン ド 2 , バンド 3 の順になる。本研究ではこのようなパ スラジアンス項を元のディジタル值から引くことによ り，大気の影響を補正した。表 2 は引いたパスラジア ンス項のディジタル值である。この值は研究地域の七 ストグラムを算出し, 最小值を計算する項によって得 られた。パスラジアンス項の值がデータごとに異なる のは，人工衛星センサーがそれぞれのデー夕によって 異なる大気条件を示しており，パスラジアンスの影響 がいちばん強いバンド 1 の值がその影響を良く表して いる。

Table 2 Pathradiance values at each band of Landsat data used in the present study

\begin{tabular}{lcccc}
\hline Data No. & No.1 & No.2 & No.3 & No.4 \\
\hline Date & $1986 / 07 / 15$ & $1988 / 12 / 27$ & $1989 / 03 / 01$ & $1989 / 09 / 25$ \\
Band-1 & 69 & 56 & 64 & 60 \\
Band-2 & 20 & 17 & 18 & 17 \\
Band-3 & 14 & 12 & 12 & 11 \\
\hline
\end{tabular}

また，太陽高度の補正は，前述した幾何補正が行わ れた後, 385地点のサンプリングポイントを太陽高度が 異なる 4 つの画像上で 1 ポイントあたり 4 つづつ，全 部で1540個のデジタル值を取り集め，デジタル值と太 陽高度の間の相関係数を求めた。補正の内容は，求め た係数により,全部のデー夕を太陽高度 $90^{\circ}$ に変換し, 太陽高度によって生じた大気の影響を補正した。式(5),
(6)，(7)は，回帰分析を用いて求めたもので，各バンド のデジタル值を太陽高度 $90^{\circ}$ に変換するために使っ た。

$$
\begin{aligned}
& \text { band }-1=0.081 * \text { sun el. }+6.618(\mathrm{r}=0.88) \quad \cdots(5) \\
& \text { band }-2=0.033 * \text { sun el. }+3.191(\mathrm{r}=0.74) \quad \cdots(6) \\
& \text { band }-3=0.040 * \text { sun el. }+1.927(\mathrm{r}=0.95) \quad \cdots(7)
\end{aligned}
$$

\section{3 海面の高さの補正}

Fig. 2 は本研究で行った海面の高さの補正方法を示 している。図は各々の画像 $(-1,-2,-3,-4)$ が, 潮位の 高さの異なる時間に取られていることを示している。 基準潮位の高さは平均水面であり, 画像 1 は平均水面 より潮位が低い時刻に，また画像 $2 ， 3 ， 4$ は，平均 水面より潮位の高い時刻に撮影したことになる。

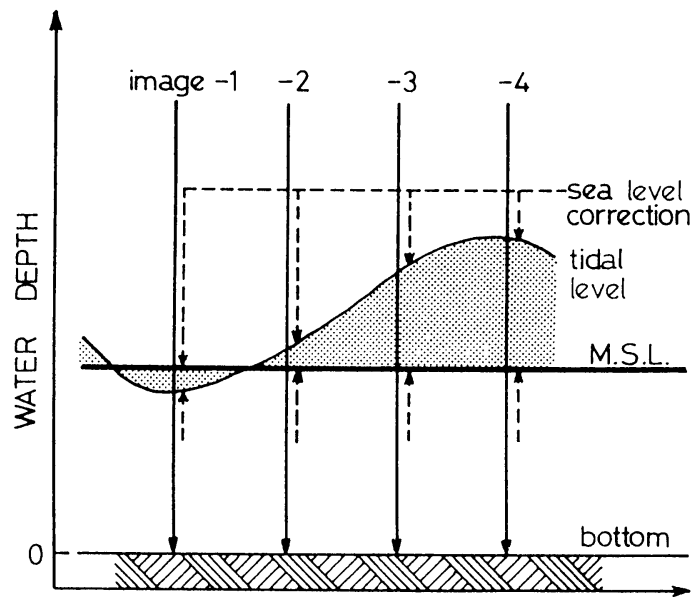

IMAGE SENSING TIME

Fig. 2 Schematic diagram of sea level correction

本研究で用いた金武湾のデータの場合, 全部が平均 水面以上の時刻に取られたデータであった。また現場 の水深デー夕值は, 基本水準面を基準とした值となっ ているので, 画像のデー夕との比較のため, 平均水面 を基準とした海面の高さを画像の撮影時刻に補正し た。

補正の計算式としては，気象庁が提案した式を利用 した ${ }^{12)}$ 。その結果， 86 年 7 月，88年12月，89年 3 月， 89 年 9 月の順に，オリジナルデー夕に対して $+1.19 \mathrm{~m}$, $+1.66 \mathrm{~m},+1.44 \mathrm{~m},+0.59 \mathrm{~m}$ の結果となった。 


\section{6. モデル作成と海底地質の補正}

モデル式は 2 種類で, 一つは水深モデルであり，も う一つは前述した補正や水深の影響が補正された，海 底情報抽出モデルである。海底地質の補正はこの海底 情報抽出モデルにより行った。

\section{1 水深モデルと海底情報抽出モデル}

デー夕補正が行われた結果值から, 引用されたモデ ル理論（式(1)，(2)）に基づき，次のような水深推測モ デルが作成された。

$$
\begin{array}{r}
\mathrm{Zc}=22.445-5.466 * \mathrm{Xc} 1-1.385 * \mathrm{Xc} 2 \\
+0.896 * \mathrm{Xc} 3 \ldots \ldots \ldots \ldots \ldots \ldots \ldots \ldots \ldots \ldots \ldots \ldots \ldots \ldots
\end{array}
$$

$\mathrm{Zn}=66.016-10.454 * \mathrm{Xn} 1-14.871 * \mathrm{Xn} 2$

$$
+5.175 * \mathrm{Xn} 3
$$

ここで, Xc1，Xc2，Xc3およびXn1，Xn2，Xn3は， 上述のデー夕補正が行われた結果から得られたディジ タル值の Ln 值である。Xn1, Xn2, Xn3は, 海底地質 が非サンゴ礁であることを示し，Xc1，Xc2，Xc3は， 海底地質がサンゴであることを表す。各々の係数は多 項回帰分析により求めた。

このモデルの結果から得られた推測水深は, 各バン ドとの強い相関性を持っている。Fig. 3 は, 水深推測モ デルにより計算された, 推測水深と補正されたデジ夕 ル值との相関関係をバンドごとに表したものである。 図の中には, 海上保安庁の水路部 ${ }^{13}$ による海底地質図 から判断されたサンゴを白丸に，これ以外を黒丸で示 している。

この相関関係は, 作成した水深モデルから求めたも ので，既に水深の影響が考慮されている。また，水深 モデルで用いた数值は, 前述の大気と海面の高さの補 正によるデータであるため, 大気と海面の高さ補正が 考慮された相関関係となっている。

このことから, 水深推測モデルの結果值と両地質に おけるデジ夕ル值との相関関係により求められる, 海 底地質ごとの係数は, 本研究のサンゴ礁抽出の手法で あげられた条件，すなわち，(1)干満の差と，(2)大気の 影響と，(3)水深の影響などの補正を満たす式となる。

図から判断されるように，作られた水深モデルの結 果值は, サンゴ礁の場合, バンド一 1 において最も相 関性が高く，非サンゴ礁の場合，バンドー 2 で最も相 関性が高いことが分かる。その相関係数は, 各々 0.98 ,
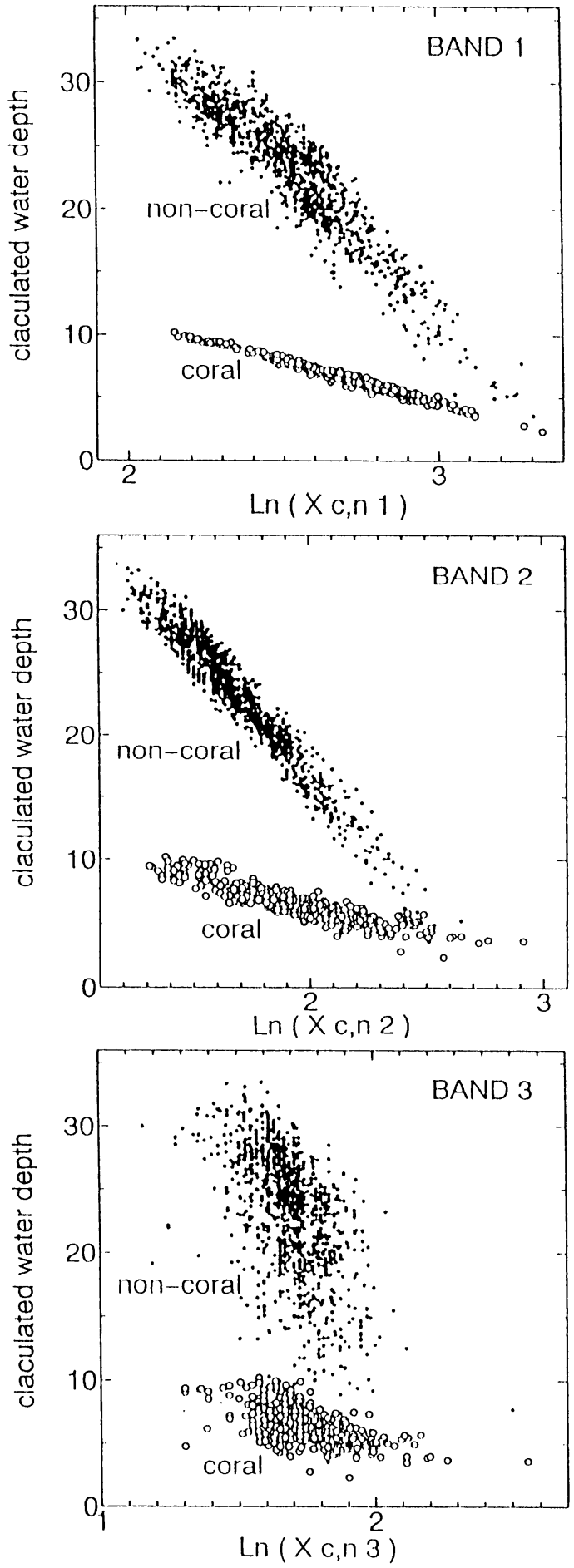

Fig. 3 Relationship between calculated water depth obtaimed by water depth model and CCT counts in each band of Landsat-5/TM 
0.95であった。このような相関関係により作成した， 海底情報抽出モデルを次の式に示す。

$\mathrm{Zcf}=24.477-6.615 * \mathrm{Xc1}$ $\cdot(10)$

$\mathrm{Znf}=58.011-20.595 * \mathrm{Xn} 2$

ここで, Zcf はサンゴ礁の判断に用いた式で, Znf は 非サンゴ礁の判断に用いた式である。

\section{2 海底地質の補正}

海底地質の補正は，地質によって異なる反射率のた め生じるエラーを補正するもので, 本研究では, 海底 地質の抽出に用いた式(10)，(11)により, 海底地質を分離 した。

海底地質の情報として用いる，海底地質情報の分離 方法を Fig. 4 に示す。四を見ると分かるように，サン ゴ礁と非サンゴ礁を代表する 2 つの海底情報モデルの 線形式（式-10，11）は，2つの海底情報を分離してい る。すなわち, この 2 つの式は, 水深 $11.25 \mathrm{~m}$ 以上の データをサンゴ礁以外の地質として, デジタル值の Ln 值が $\operatorname{Ln}$ (digital count) $=2.82$ 以上のデータをサンゴ 礁の地質として区分している。また，両者が一緒に含 まれている水深においては, 水深段階ごとに, あるデ ジタル值を区分值として 2 つ海底情報は分離でき る。罒中で暗部によって示された各水深ごとの四角の 中では, Ln 值はある区分值を中心に二分されるのであ る。

この方法は，水深や海底地質の補正ができていない デジタル值だけによる教師付き分類法や教師無し分類

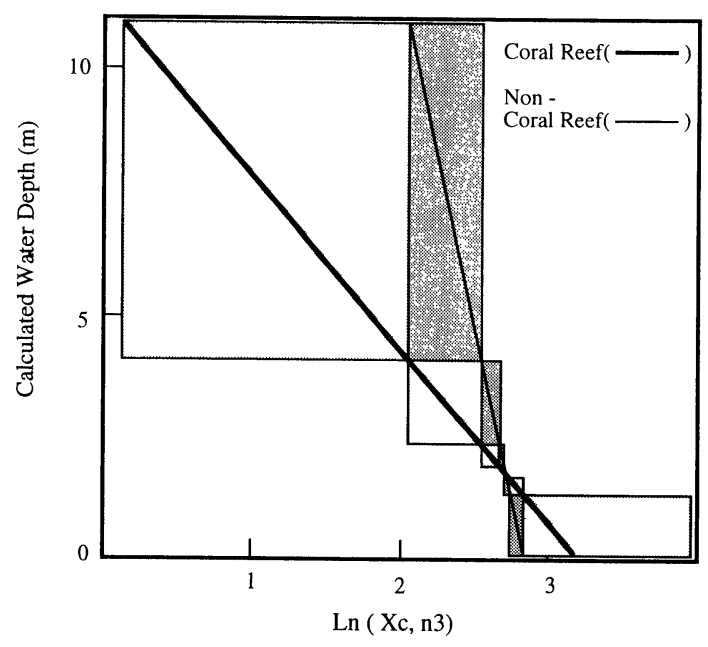

Fig. 4 Diagram to devide into two bottom conditions; coral reef and non-coral reef
法と異って水深データや大気，潮の高さ，海底地質の 情報を考慮し分類している。提案した式によるサンゴ 礁分類方法は，前述したように多くの研究で指摘した サンゴ礁分類方法の問題点を解決していることで意味 深い方法と言えよう。

次に, 抽出したサンゴ礁地域の情報図により, 海底 地質の補正が行なった水深図を作るために，海底がサ ンゴ礁の場合と非サンゴ礁の場合を区別し，各々のモ デルによりサンゴ礁と非サンゴ礁の地域の水深を計算 した。この補正過程を Fig. 5 に示す。

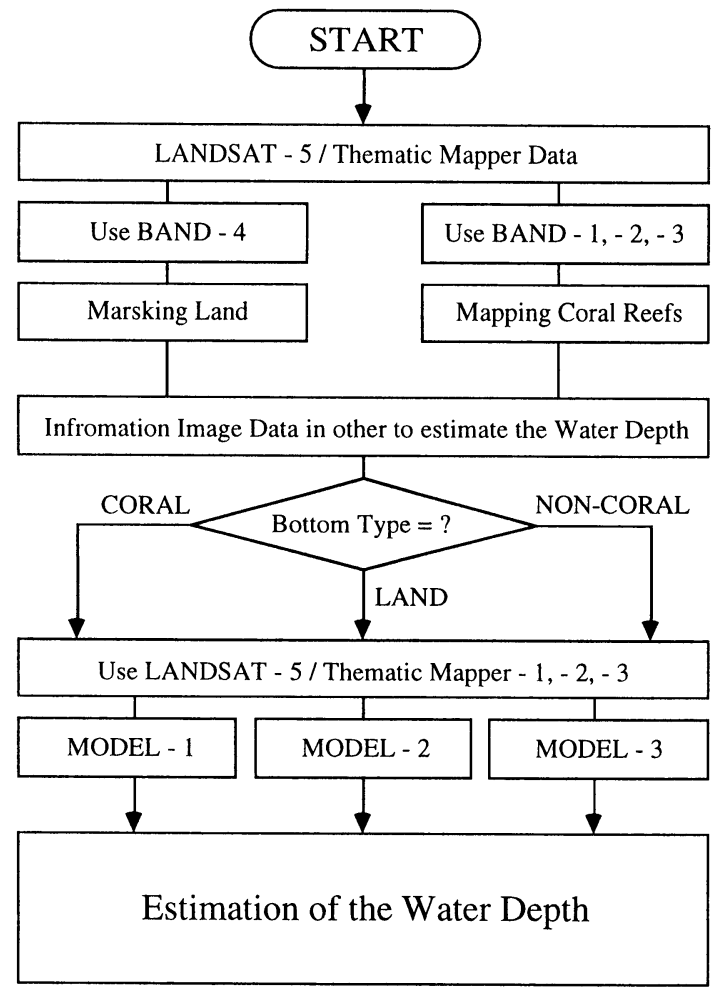

Fig. 5 Flow chart of the model processing

図の説明のように，まず，バンドー 4 により陸域を カットし，マスキング作業を行った。この結果は，陸 域と水域を区分する情報図として用いた。次は，サン ゴ礁と非サンゴ礁地域のデー夕を抽出した。このよう に2つの流れによって作られたデー夕は，陸域と水域 の区分図との重ね合わせにより，海底地質の情報図を 作り，プログラムの中で判別情報として用いた。次の 段階では，作られた海底地質の情報図が，海底がサン ゴ礁の場合と非サンゴ礁の場合を区別し，各々のモデ ルにより両区分地域の水深を計算, 海底地質による補 
正を行い水深図を作成した。

\section{7. モデルの評価}

このように求めた水深図の結果は, モデルの評価の ために，実測值と比較し，偏差を求めた。その結果を Fig. 6 に示す。結果はFig. 6(A) から判断されるよう に，結果の偏差が均等に $(+) 20 \mathrm{~m}$ から (-) $20 \mathrm{~m}$ までの 間に分布していることが分かる。しかし，多くのデー 夕は $(+) 8 \mathrm{~m}$ から $(-) 8 \mathrm{~m}$ までの間に分布している。 このデータの結果は, Fig. 6(B) から判断されるよう に，1540個の全部のデー夕を使った場合，R.M.S.が $4.23 \mathrm{~m}$ となった。しかし，雲の無い1986年 7 月のデー 夕と1988年12月のデータだけを使った770個の結果の 場合，R.M.S.が $3.38 \mathrm{~m}$ となった。Table 3 は，水深 情報を得るためのモデルとして，海底地質を考慮して いないモデル (N.B.F.M) と海底地質が考慮されたモ デル (B.F.M) として分類している。各々のモデルは 1 つのバンドを用いた単バンドモデルと 2 つ以上のバ ンドを用いた複合バンドモデルに分け，各モデルの R. M.S.エラーを比較している。その中で, 海底地質モデ ルは，デジタイザにより海底地質図を作り用いた 4 bottoms model ${ }^{1)}$ と本研究で提案した海底地質図を人 工衛星データから直接取得し用いた 2 bottoms model に分けている。さらに, 2 bottoms model は, 1540デー 夕を全部使った結果 (all data) と，770個の雲無しデー タだけを使った結果（clear data）と分けている。2

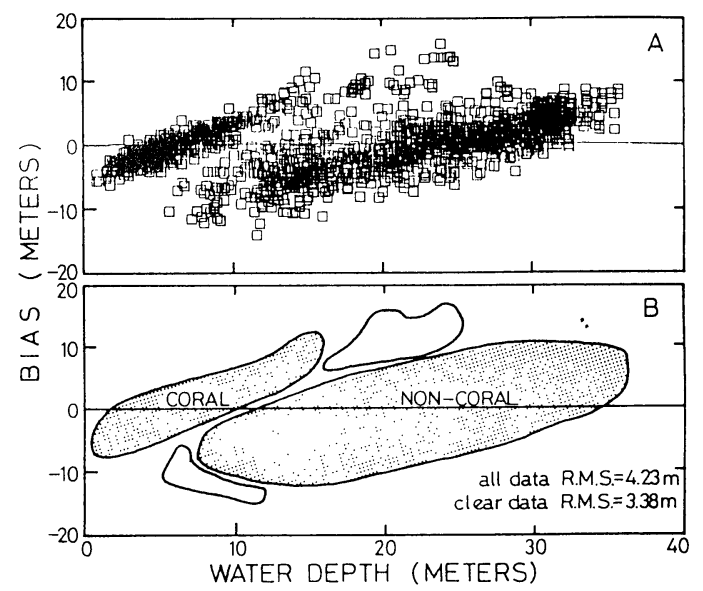

Fig. 6 Calculated results of coral, and non-coral region (A), and actual distribution map of two region (B) bottom model は, 精度の良い multi-model だけの結 果である。

以上の結果から, 水深は海底地質が考慮されていな いモデルより，海底地質が考慮されたモデルの結果值 がすべて良くなっていることが伺える。しかし，本研 究の手法のように，海底情報を衛星デー夕から取り， サンゴ礁,非サンゴ礁の 2 つ種類の情報を用いる場合, 海底情報をデジタイザにより入力し，4つの海底情報 を用いた（Table $3 の 4$ bottoms）結果よりは，精度 が落ちている。これは，分けられていない海底情報の 影響が及んだ結果であると考えられる。しかし，本研 究により開発されたモデルは，海底地質が考虑されて いない複合モデル（Table 3 の N.B.F.M multi model）よりは精度が上がっており，雲の影響がない データの結果からみると，4つの海底地質の情報が考 慮された場合との差は少ない。これは水深推測をする 際，大きく影響を与えている海底地質はサンゴ礁であ ることを説明するものであり，サンゴ礁と非サンゴ礁 の地域を考慮することだけでも良い結果が求められる ことを意味する。

海底情報や水深などが精密に調査されていない地域 は，未だ多く存在している。特に，本研究で取り上げ た地域のように，サンゴ礁が卓越している地域におい ては，この傾向は強い。本研究の結果は，このように 精密な現地調查が行われていない地域において，海底 情報（サンゴ礁，非サンゴ礁）の区分および水深推測 をする際，大きな誤差なしに，水深情報が得られる可 能性を示唆している。

Table 3 R.M.S. value of each models used in the present study

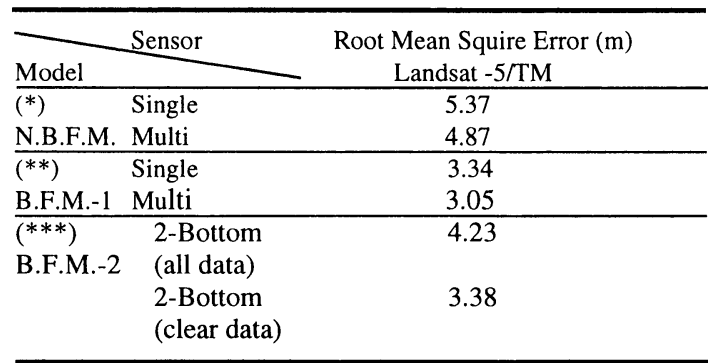

(*):Non Bottom Feature Model $(* *)$ :Bottom Feature Model-1

$(* * *)$ :Bottom Feature Model-2 

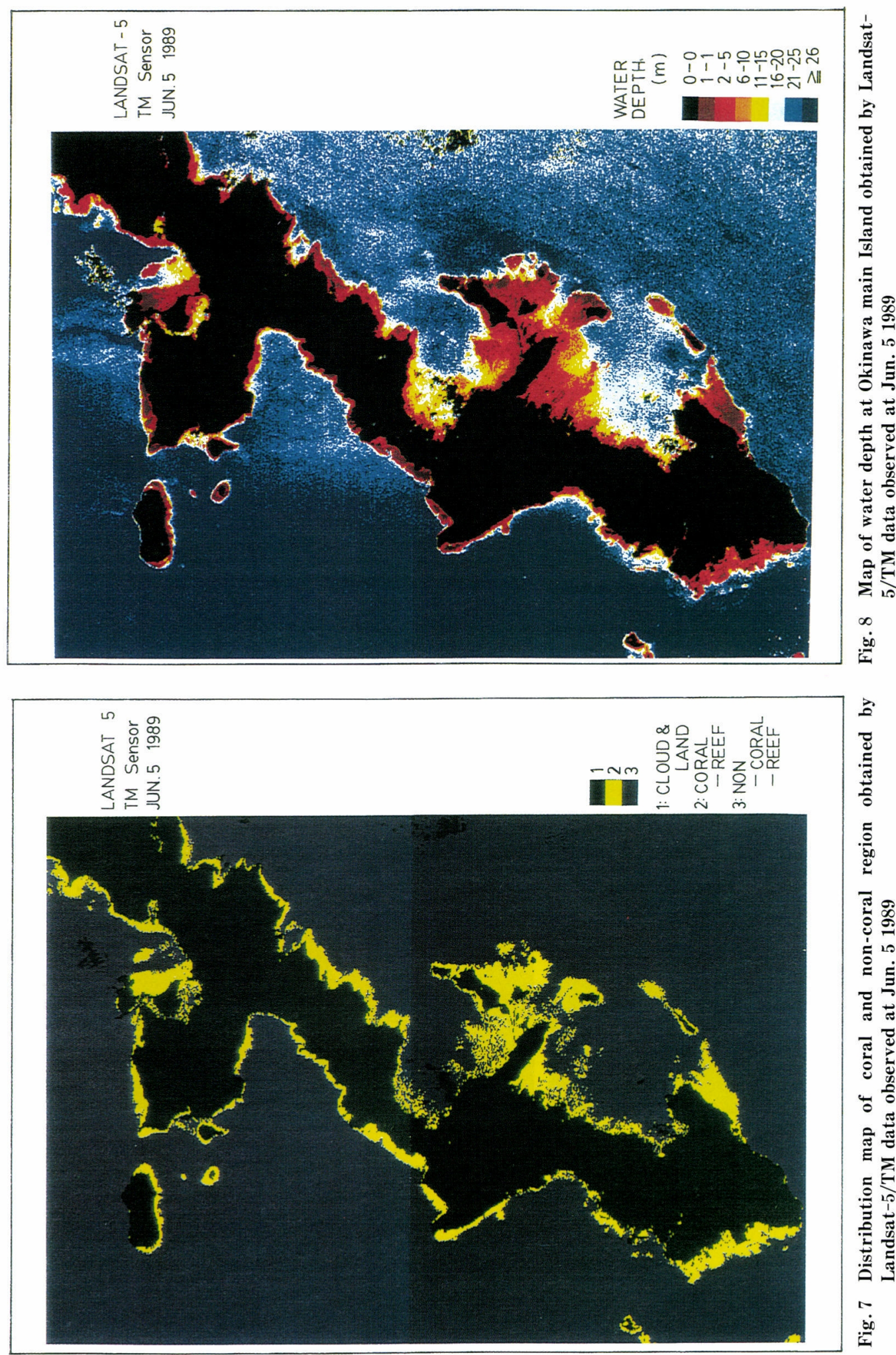

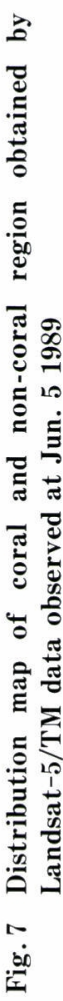




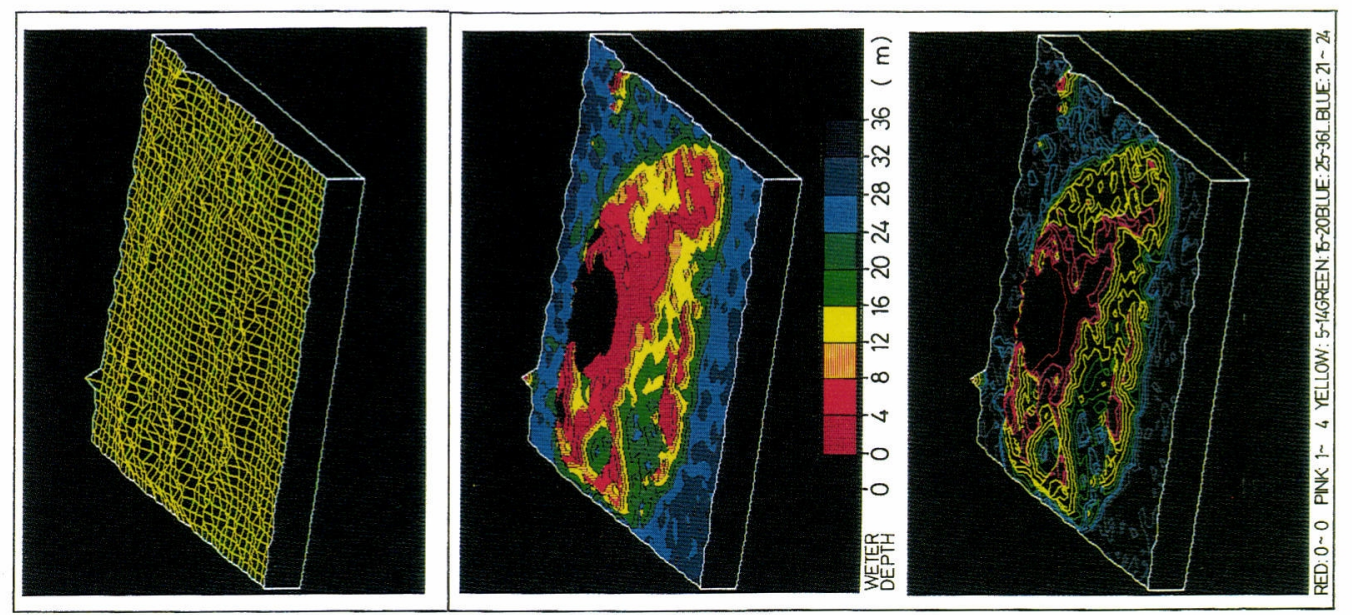

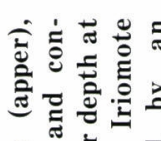

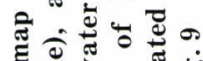

घ

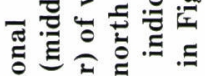

这

की

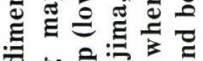

ช0

ญ

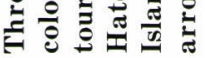

으

$\dot{00}$

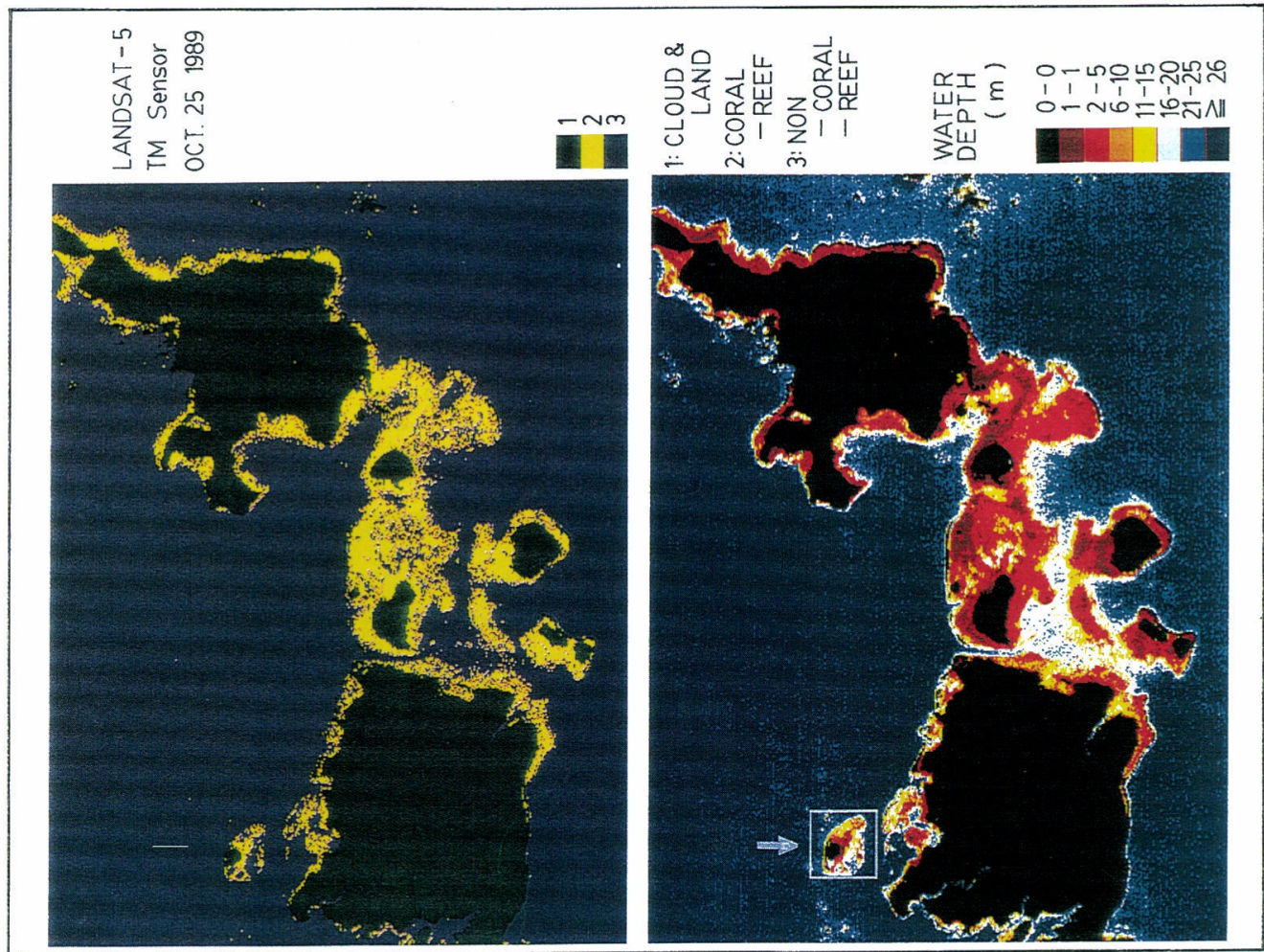

号

荡苍

뜰

西

茐

氙

这这

르 촗

돌

苟

츨

온

: 5

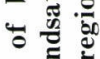

芷需

ธฮّ

赅

is 


\section{8. モデルの適用と 3 次元表現}

本研究のモデルと手法は, 沖縄本島と八重山諸島に 適用した。その結果を Fig. 7 9 までに示す。Fig. 7, Fig. 9(a)は，6.1で述べた海底情報抽出モデルにより， 得られたサンゴ礁の情報であり, Fig. 8, Fig. 9(b)は, 本研究で提案した手法により, 抽出した水深結果であ る。特に, Fig. 9 は, まだ海上保安庁の水路部により海 の基本困が作られていないところで，本研究で提案し た方法により分類したサンゴ礁の分布図 (a) と，水深 推測図（b）である。また，Fig. 9(b) では，白い線に 囲まれている地域の水深を 3 次元で表現しており (Fig. 10 (a)), 水深別に等水深線を抽出し，カラースラ イス画像を作成した（Fig. 10 (b))。また，コンタライ ン別に色線を引き，視覚に訴之易く表現した（Fig. 10 (c))。これは人工衛星から水深図のコンタラインを作 成する可能性を試みたものであり，その結果は，十分 な可能性を示すものとなった。海上保安庁からの情報 (私信)によれば，沖縄本島における 5 万分の 1 の海の 基本図が作られるのに水深調査を含めた調查経費とし て，ランドサットデータ購入費の数百倍も必要として いる。今後，まだ調査されていない地域の開発や準備 調查として, 広域性と反復性, 同時性, 経済性の利点 を備えた人工衛星情報による海底情報四や水深推測 図，また水梁のコンタラインの抽出は，多くの有益性 を持つものと思われる。

\section{9. 今後の課題}

Table 3 の結果から, 海底の情報をサンゴ礁と非サ ンゴ礁の 2 つに分類するときには，4 種類に分類して 行った水深推測の結果より誤差が増加しており, Fig. 6 からは, 水深が浅くなると推測水深はより下方に評 価され，水深が深くなるとより上方に評価される傾向 がみられる。このことは，本論文で考慮していない海 底情報の影響や水質の影響が及ぼす結果であると思わ れる。しかし，サンゴ礁が卓越している地域の透明度 が一定以上であるとすれば，その大きな影響は海底地 質の影響であると思われる。上記のような誤差を無く すための研究が今後の課題である。

本研究を進めるに当たって, 水深原図を提供して下
さった海上保安庁水路部と大気補正の方法について多 くの助言をして下さった, 長崎大学工学部機械システ ム工学科の森山助教授には, 記して感謝の意を表する 次第である。

(受付；94.2.7, 受理；94.7.12)

\section{参 考 文 献}

1）全 炳徳・後藤恵之輔：水深推測のためのリモートセ ンシング手法の比較と提案, リモートセンシング学会誌, Vol.13, No.4, pp.41-50, 1993.

2 ) V.E. Smith, R.H. Roger and L.E. Reed: Automated Mapping and Inventory of Great Barrier Reef Zonation with Landsat Data, IEEE OCEAN '75, New York, pp. 775-780, 1975.

3 ) R.T. Bina, K. Carpenter, W. Zacher, R. Jara and J. B. Lim: Coral reef Mapping using Landsat data, follow-up studies, Proceedings Twelfth International Symposium Remote Sensing Environment, Ann Arbor, Michigan, pp. 42051-2070, 1978.

4 ）アジア航測(森：ランドサットデー夕による海域情報処 理システムの調査報告書, 1980 .

5) P.A. Pirazzoli : Bathymetric Mapping of Coral Reefs and a tolls from satellite, Proceedings of Fifth International Coral Reef Congress, Vol. 6, pp. 539-544, 1985.

6 ) F.C. Polcyn and I.J. Sattinger : Water Depth Determinations using RemoteSensing Techniques, Proceedings of SixthInternational Symposium on Remote Sensing of the Environment, Ann Arbor, Michigan, pp. 1017-1028, 1969.

7) C.T. Wezernak and D.R. Lyzenga: Analysis of Cladophora Distribution in Lake Ontario using Remote Sensing, Remote Sensing of Environment, Vol. 4, pp. 37-48, 1975.

$8)$ B.D. Jun, K. Gotoh, Y. Tanabashi and Sam Wouthyzen: The Extraction of Bottom Characteristics and Mapping in Kin Bay, Okinawa Main Ialand, Japan using Landsat-5/TM and SPOT-1/HRV data., Proceedings of PORSEC '92, Vol. 1, pp. 211-216, 1992.

9 ） 全 炳徳・後藤恵之輔・サムウオウトウゼン：ランド サット TM デー夕による海底地質を考慮した水深推測 モデルの開発, 海洋開発論文集, Vol.7, pp.189-193, 1991.

10）高木幹雄ほか：画像解析ハンドブック, 東京大学出版 会, pp.423-429, 1991.

11) Warren A. Hovis : Measurements of Ocean Color, Proceeding of a Symp. on the Significant Accomplishments in Sciences, NASA Goddard Flight Center, Greenbelt, Md., pp. 24-29, 1971.

12）気象庁：潮位表, 1988 .

13）海上保安庁水路部：5 万分の 1 沿岸の海の基本図：海 底地形地質調査報告 (金武湾), 1988.3。 